\title{
Editorial 53
}

\author{
Eric R. Scerri ${ }^{1}$
}

Published online: 4 June 2016

(C) Springer Science+Business Media Dordrecht 2016

The present issue consists almost entirely of papers that were first presented at the $18^{\text {th }}$ annual meeting of the International Society for the Philosophy of Chemistry held, in 2014, at the London School of Economics. ${ }^{1}$ The conference was beautifully organized by Rom Harré with the assistance of Roman Frigg. Rom Harré also kindly agreed to edit the articles and has produced a brief editorial to put the contributions into context.

As Harré points out, the issue is dedicated to the memory of the Estonian philosopher of chemistry, Rein Vihalemm who recently passed away as a result of an accident, We will all miss Rein's gentle presence and distinctive presentations at annual meetings dating back to the early days in the 1990s.

The issue is rounded off by an interesting contribution on the foundations of the periodic table by Naum Imyanitov, an author based in St. Petersberg who has published previously in this journal. Finally we have a book review by the ever-present historian of chemistry extraordinaire, George Kauffman.

As this issue goes to press we prepare to meet again at the 20th annual meeting of the society to be held in Boca Raton, Florida under the auspices of Marina Banchetti, who is also a contributors to Rom Harré's special issue. ${ }^{2}$

\footnotetext{
1 https://sites.google.com/site/socphilchem/.

${ }^{2}$ https://sites.google.com/site/ispc2016/home-1.
}

Eric R. Scerri

scerri@chem.ucla.edu;

http://www.ericscerri.com

1 Department of Chemistry and Biochemistry, UCLA, Los Angeles, CA 90095, USA 